\title{
EFFECT OF DIETARY LUPIN (Lupinus angustifolius) WHOLE- SEED MEAL PROTEIN ON THE GROWTH OF TILAPIA (Oreochromis niloticus) REARED IN TANKS
}

T.M. Srour

\author{
Department of Animal and Fish Production, Faculty of Agriculture (Saba Basha), \\ University of Alexandria
}

\section{SUMMARY}

A factorial feeding experiment $(2 \times 5)$ was conducted in indoor circular $1 \mathrm{~m}^{3}$ fiberglass tanks to evaluate the effect of different levels of un-cooked and cooked lupin whole-seed meal protein, at the expense of fish meal (FM) protein, on the growth of Nile tilapia, Oreochromis niloticus, fingerlings (3 g/fish). Nine isocaloric and isonitogenous diets (25\% protein) were formulated where FM protein was replaced partially by 0,15, 30, 45 and $60 \%$ of un-cooked or cooked whole lupin seed meal protein. Tanks were stocked with 15 fish/tank in duplicate groups/treatment. Fish were fed daily at a rate of $3 \%$ of fish live body weight for 14 weeks. The results indicated that fish receiving diets containing uncooked lupin protein were better in growth performance, feed and nutrient utilization than those fed cooked lupin protein. Growth performance, feed intake, feed conversion ratio and energy utilization began to deteriorate significantly at $45 \%$ lupin protein. Protein efficiency ratio and protein productive values declined significantly subsequent to $30 \%$ lupin protein level. Fish fed diets containing 0, 15 and $30 \%$ lupin protein gained preferable FCR. Dry matter and hepatosomatic index were not affected by lupin protein levels or lupin treatments whil, ash and gross energy contents were affected by lupin protein levels but not lupin treatments. Meanwhile, crude protein and ether extract were affected by both lupin protein levels and lupin treatments. The economic evaluation was in favor of diets containing 15, 30 and $60 \%$ un-cooked in addition to $30 \%$ cooked lupin protein. However, the results of this study indicate that up to and including $30 \%$ lupin protein could replace FM protein in Nile tilapia diets without any retardation in growth.

\section{INTRODUCTION}

In order to produce fish economically, formulated feeds are required. Protein requirement for fish in general is higher than that of livestock. Fish meal (FM) has been a prominent protein source used in most fish feed formulations. Otherwise, FM is usually used with high level in fish diets (Tacon and Jackson, 1985). However, due to the high cost of FM, there has been interest in, at least partially, replacing this ingredient with less expensive, available and good nutritional value plant protein sources in aquaculture feeds (Hardy, 1996). Most modern, nutrient-dense, aquaculture diets use some of plant protein ingredients (Palmegiano, et al., 2006). Lupin (Lupinus spp.) was shown to provide some potential as a useful feed ingredient in fish diets and has been used in commercial diets in some countries (Burel et al., 1998; Glencross et al., 2002; 2003; 2006a and 2006b).

Issued by The Egyptian Society of Animal Production 
In comparison to other plant protein sources, the potential of lupin is equaled perhaps only by soybean meals, which are presently widely accepted and used in the aquaculture feeds sector. Although the occurrence of alkaloids in soybean are not detected, lupin contains lower amounts of trypsin inhibitor, oligosaccharides and phytate compared to those detected in soybean (Petterson, et al., 1997 and Sitja'Bobadillaa, et al., 2005). In many instances, the digestibility of lupin protein has been significantly superior to that of many other plant protein and/or animal protein sources (Hughes, 1988; Gomes et al., 1995; Burel et al., 2000; Smith et al., 2000 and Booth et al., 2001). The highly digestible protein and lipid components of lupin meals constitute almost the entire digestible energy value of this seed source (Allan et al., 1998; Burel et al., 2000; Kissil and Lupatsch, 2000). Gomes et al. (1995) found that the digestibility (\%) of dry matter, protein and energy for FM and $L$. angustifolius whole seed meal were 78.0, 86.6 and 69.7 for FM and 63.3, 85.5 and 61.2 for lupin, respectively.

Additionally, lupin seeds have been used as a key feed ingredient in diet formulations for terrestrial livestock species (Petterson, 2000). Petterson et al. (1998) demonstrated that in low-specification diets for tilapia, the partial replacement of FM and/or soybean could be effectively achieved with $L$. angustifolius kernel meal. Meanwhile, performance of milkfish fed diets containing incremented levels of $L$. angustifolius kernel meal from $0 \%$ to $100 \%$ as FM replacer, apparently improved with increasing lupin in the diet. The best performance of milkfish fed the experimental diets was observed with those fed the $100 \%$ L. angustifolius kernel meal diet (Petterson, 2000). On the other hand, Refstie, et al. (2006) stated that the tested lupin kernel meals and protein concentrates did not alter the intestinal function in Atlantic salmon when included at $30 \%$ of the diet. Also in a study on rainbow trout by Glencross, et al. (2004 and 2006a) concluded that lupin is a highly useful feed ingredient for aquaculture rations.

There is a considerable variability in reports on maximum inclusion level of lupin meals in diets for aquaculture species with values ranging from $20 \%$ to $70 \%$ (De la Higuera et al., 1988; Robaina et al., 1995; Burel et al., 1998; Saraç et al., 1998 and Williams, 1998). As with other protein sources, the maximum inclusion is likely to be a function of the protein content of source used, the protein requirements of the animal and the level of feed attractants and ingestants included in the diet. Otherwise, alkaloids are one of the anti-nutritional factors found in lupin, which are typically low. Present levels of alkaloids in L. angustifolius are usually less than $200 \mathrm{mg} / \mathrm{kg}$ (Harris and Jago, 1984). Robaina et al. (1995) demonstrated that heat-treated and soaked lupin seeds in water for $24 \mathrm{~h}$ remove excess alkaloids.

There are few reports, however, on the nutritional or biological value of lupin when fed to fish species (Glencross et al., 2002). Also, there is no clear study examining the influence of inclusion levels of this ingredient whether un-cooked or cooked in the diets of local fish in Egypt. Therefore, this study examines the influence of incremental inclusion of un-cooked or cooked lupin protein at the expense of fish meal protein in the diet of Nile tilapia (Oreochromis niloticus) with a simple economic evaluation. 


\section{MATERIALS AND METHODS}

The experiment was carried out at the Laboratory of Fish Nutrition, Faculty of Agriculture (Saba Basha), Alexandria University.

\section{Fish and culture facilities}

The feeding trial was conducted in twenty circular fiberglass tanks (each of $1 \mathrm{~m}^{3}$ ) kept an in-indoor laboratory. Nile tilapia, Oreochromis niloticus, fingerlings were obtained from the Experimental Fish Farm of Agriculture Faculty (Saba Basha) (the $10^{\text {th }}$ Village, Abbis, Alexandria). Fish were randomly allocated to each tank in duplicates (15 fish/tank) per treatment, and adapated to the experimental conditions for 7 days. Average individual fish weight at the start of the study was $3 \mathrm{~g}$. Subsequently, fish from each replicate were weighed at fortnightly intervals during the experimental period and the daily amount of feeds were readjusted as percentage of live body weight. About 20 fish were frozen for initial proximate body chemical analysis. The indoor laboratory was covered with light transparent fiberglass sheets to allow natural light The experimental tanks were cleaned every morning before the first feeding, and about one fourth of the water was replaced by a mixture of fresh dechlorinated tap and ground water. Water level was maintained at $0.8 \mathrm{~m}^{3}$ throughout the experimental period, water temperature was checked daily, and ranged between 25 and $27^{\circ} \mathrm{C}$. Dissolved oxygen was kept close to saturation level by continuous aeration.

\section{Experimental diets}

Ingredients were bought from the local market and the dry ingredients were first ground to fine particles. The calculated amount of lupin (Lupinus angustifolius) whole-seed were divided into two divisions. The first division was ground to small particles in size, and the second was cooked in a pressure cooker for 15 min (Jayaram and Shetty, 1981) then kept in a plastic dispenser where water was changed three times a day for three days to remove the alkaloid substances then dried and finally ground to small particles. Afterward, both of cooked and un-cooked powdered lupins were incorporated separately into the diets, where, un-cooked or cooked lupin protein whole-seed meal replaced FM protein at a level of 0, 15, 30, 45 and $60 \%$ (Table 2). All diets were sufficient in essential vitamins and trace minerals (NRC, 1993). Diet ingredients were thoroughly mixed in a plastic container. The oil was added, a few drops at a time, during mixing. Warm water $\left(45^{\circ} \mathrm{C}\right)$ was slowly added under continuous mixing until the diets began to clump. The diets were passed through commercial meat mincer 3 times, and dried for $24 \mathrm{hrs}$ at $80^{\circ} \mathrm{C}$ in a drying oven. Dried diets were stored in a freezer at $-20^{\circ} \mathrm{C}$ throughout the experimental period. All diets were formulated to be isonitrogenous ( $25 \%$ protein, according to Jauncey and Ross (1982) and NRC (1993) and isocaloric. The diets were fed to the experimental fish two times a day $(09,00$ and $15,00 \mathrm{hr})$ at a rate of $3 \%$ of live body weight on feed dry weight basis for 14 weeks (6 days a week).

\section{Samples collection and analysis}

At the termination of the experiments, fish were collected, weighed and counted per each replicate in each treatment. The samples from each experimental unit were oven dried at $60-80^{\circ} \mathrm{C}$ for $48 \mathrm{hrs}$, and then ground to minute particles. Finally, fish samples and the experimental diets were submitted to proximate chemical analyses following the AOAC (1999) standard procedures. The nutrition equations were used 
according to Hepher (1988). All data were analyzed for statistical significance by using analysis of variance and examined by linear regression modeling (Stat View 5.0 computing package). The least significant difference (LSD) multiple comparison test was used to identify significant differences among treatment means (Steel and Torrie, 1980).

\section{RESULTS AND DISCUSSION}

The chemical analysis of fish meal (FM) in comparison with un-cooked and cooked lupin is presented in Table 1. The results revealed that crude protein, ether extract and ash contents were higher in FM while the contents of dry matter were similar to un-cooked and cooked lupin. The chemical composition of un-cooked and cooked lupin was almost paralle while numerically, un-cooked lupin contained higher ash and nitrogen free extract than cooked lupin. Otherwise, cooked lupin contained higher amount of dry matter, crude protein, ether extract, crude fiber and gross energy. Likewise, Petterson et al. (1997) found that Lupin seeds are typified by higher protein content ( 31 to $42 \%$ ) than most other grain legumes. There is considerable variation in the protein content between the various species and between cultivars and even within cultivars as a result of growing season and soil type.

Table 1. Chemical composition of fish meal and lupin (un-cooked and cooked) as percentage of dry matter basis

\begin{tabular}{|c|c|c|c|c|c|c|c|}
\hline \multirow{2}{*}{ Ingredients } & \multicolumn{6}{|c|}{ Composition (\%) } & \multirow{2}{*}{$\begin{array}{c}\text { Gross } \\
\text { energy* }\end{array}$} \\
\hline & DM & $\mathbf{C P}$ & $\mathbf{E E}$ & Ash & $\mathbf{C F}$ & NFE & \\
\hline Fish meal & 89.5 & 60 & 15 & 24 & 1 & - & 480.00 \\
\hline Un-cooked lupin & 88.2 & 40 & 11.5 & 3.4 & 12.6 & 32.5 & 467.74 \\
\hline Cooked lupin & 88.8 & 41 & 12.5 & 2.7 & 12.8 & 31.0 & 476.65 \\
\hline \multicolumn{8}{|c|}{$\begin{array}{l}\mathrm{DM}=\text { Dry matter; } \mathrm{CP}=\text { Crude protein; } \mathrm{EE}=\text { Ether extract; } \mathrm{CF}=\text { Crude fiber and NFE = Nitrogen free } \\
\text { extract. } \\
* \text { Gross energy }(\mathrm{Kcal} / 100 \mathrm{~g} \mathrm{DM}) \text {, calculated on the basis of } 5.64,4.11 \text { and } 9.44 \mathrm{Kcal} \mathrm{GE} / \mathrm{g} \text { protein, NFE } \\
\text { and lipid, respectively }(\mathrm{NRC}, 1993) \text {. }\end{array}$} \\
\hline
\end{tabular}

The results of chemical composition revealed that all diets were almost isocaloric (about $426.21 \mathrm{Kcal} / 100 \mathrm{~g}$ dry matter) and isonitogenous (24.94 \% crude protein). The mean value of protein to energy ratio (P:E ratio) was $58.51 \mathrm{mg}$ protein/Kcal gross energy. As the level of lupin whether uncooked or cooked in different diets increase, nitrogen free extract and crude fiber were slightly incremented while ash contents were decreased.

The effect of replacing FM protein by different levels of un-cooked or cooked lupin protein on protein in the diet and on growth performance is presented in Table 3 and the linear regression in Table 4 . Fish receiving diets containing uncooked lupin protein had significantly $(P<0.05)$ better growth performance than those fed cooked lupin protein . Results of final weight ( $\mathrm{g} / \mathrm{fish})$, gain $(\mathrm{g} / \mathrm{fish})$, average daily gain (ADG, mg/fish/day), specific growth rate (SGR, \%) and daily growth coefficient (DGC, \%/day) followed a similar pattern for fish receiving diets containing 0,15 and $30 \%$ lupin protein but revealed significantly $(P<0.05)$ higher values of growth performance compared to 45 and $60 \%$ lupin protein replacements of FM protein. 
Non significant differences were obtained when lupin protein was incremented up to $30 \%$, however, the difference between 45 and 60 of lupin protein levels was significant. Relationships between growth and the inclusion level of either cooked or un-cooked L. albus whole-seed meal were poor (De la Higuera et al., 1988). This supports the present result where no significant effect was noted due to cooking of lupins. An assimilated study by Viola et al. (1988) examined different inclusion levels of whole-seed L. angustifolius at the expense of fishmeal, for 41 days in diets for common carp (Cyprinus carpio) of $225 \mathrm{~g}$. The results indicated that there were no significant differences in growth parameters at $45 \%$ inclusion level. Also, the results obtained in the present study are in partial agreement with those of Burel et al. (1998) who examined the inclusion of (Lupinus albus) kernel meal in diets for rainbow trout at $30 \%, 50 \%$ and $70 \%$ in diets. They found that L. albus kernel meal could be included in the diet of rainbow trout up to a level of $50 \%$ with no loss in growth rate. The inclusion of $L$. albus kernel meal at $70 \%$ however, resulted in poorer growth. It was suggested that the loss in growth performance of fish fed the diets containing $70 \%$ of L. albus was attributed to low feed intakes of this diet. Since the high levels of $L$. albus kernel meal inclusion resulted in a loss of palatability due to high alkaloid contents (Petterson et al., 1997). Furthermore, in a study for 42 day on rainbow trout ( $35.8 \mathrm{~g} /$ fish) by Glencross, et al. (2004) the growth of fish was significantly reduced at $50 \%$ lupin inclusion level, but linear regression modeling suggested a decline in final weight, gain and daily growth coefficient at each inclusion level.

Table 2. Ingredients and chemical composition of the experimental diets containing various levels of cooked and uncooked lupin fed to Nile tilapia

\begin{tabular}{|c|c|c|c|c|c|c|c|c|c|}
\hline \multirow{2}{*}{ Items } & \multicolumn{9}{|c|}{ Diets No. } \\
\hline & 1 & 2 & 3 & 4 & 5 & 6 & 7 & 8 & 9 \\
\hline \multicolumn{10}{|l|}{ Ingredients (\%) } \\
\hline Fish meal & 18 & 15.3 & 12.6 & 9.9 & 7.20 & 15.3 & 12.6 & 9.9 & 7.20 \\
\hline Lupin meal & - & 4.05 & 8.1 & 12.15 & 16.2 & 3.95 & 7.90 & 11.85 & 15.81 \\
\hline Soy bean meal & 23 & 23 & 23 & 23 & 23 & 23 & 23 & 23 & 23 \\
\hline Yellow corn & 28 & 28 & 28 & 28 & 28 & 28 & 28 & 28 & 28 \\
\hline Wheat bran & 14 & 14 & 14 & 14 & 14 & 14 & 14 & 14 & 14 \\
\hline Rice particles & 14.8 & 10.5 & 9.4 & 8.15 & 7.2 & 10.6 & 9.6 & 8.45 & 7.59 \\
\hline Vegetable oil & 0.2 & 3.15 & 2.9 & 2.8 & 2.40 & 3.15 & 2.9 & 2.8 & 2.40 \\
\hline Vit. \& Min. ${ }^{1}$ & 2 & 2 & 2 & 2 & 2 & 2 & 2 & 2 & 2 \\
\hline \multicolumn{10}{|c|}{ Proximate composition (\%) } \\
\hline Dry matter & 88.7 & 89.24 & 89.02 & 88.83 & 88.70 & 89.11 & 88.93 & 88.75 & 88.61 \\
\hline \multicolumn{10}{|c|}{ On dry matter basis (\%) } \\
\hline Crude protein & 25.05 & 25.01 & 24.95 & 24.87 & 24.80 & 25.03 & 25.03 & 24.88 & 24.83 \\
\hline Ether extract & 7.73 & 7.64 & 7.56 & 7.67 & 7.66 & 7.64 & 7.65 & 7.66 & 7.67 \\
\hline NFE & 51.32 & 51.58 & 51.89 & 52.04 & 52.32 & 51.58 & 51.86 & 52.1 & 52.40 \\
\hline Crude fiber & 4.6 & 5.09 & 5.61 & 6.11 & 6.61 & 5.09 & 5.60 & 6.10 & 6.60 \\
\hline Ash & 11.3 & 10.68 & 9.99 & 9.31 & 8.61 & 10.66 & 9.86 & 9.26 & 8.5 \\
\hline Gross energy $^{2}$ & 425.18 & 425.17 & 425.35 & 426.56 & 427.22 & 425.29 & 426.53 & 426.77 & 427.81 \\
\hline P:E ratio ${ }^{3}$ & 58.92 & 58.82 & 58.66 & 58.30 & 58.05 & 58.85 & 58.68 & 58.30 & 58.04 \\
\hline \multicolumn{10}{|c|}{$\begin{array}{l}\text { Diets } 1,2,3,4 \text { and } 5 \text { contained } 0,15,30,45 \text { and } 60 \% \text { un-cooked lupin protein, respectively. } \\
\text { Diets } 6,7,8 \text { and } 9 \text { were } 15,30,45 \text { and } 60 \% \text { cooked lupin protein, respectively. }\end{array}$} \\
\hline \multicolumn{10}{|c|}{$\begin{array}{l}\text { Meveco premix, Vit. \& Min., every } 1.5 \mathrm{~kg} \text { contains Vit. A } 125 \text { million IU, } \mathrm{D}_{3} 3 \text { million IU, E } 15 \mathrm{~g}, \mathrm{~K}_{3} 2.5 \\
\mathrm{~g}, \mathrm{~B}_{1} 1.5 \mathrm{~g}, \mathrm{~B}_{2} 5 \mathrm{~g}, \mathrm{~B}_{6} 2 \mathrm{~g} \text {, Pantothanic acid } 10 \mathrm{~g}, \mathrm{~B}_{12} 0.01 \mathrm{~g} \text {, Nicotenic acid } 30 \mathrm{~g} \text {, , Folic acid } 1.2 \mathrm{~g} \text {, Fe } 30 \mathrm{~g} \text {, } \\
\mathrm{Mn} 60 \mathrm{~g}, \mathrm{Cu} 10 \mathrm{~g}, \mathrm{I} 1 \mathrm{~g} \text {, Cobalt } 0.25 \mathrm{~g}, \mathrm{Se} 10 \mathrm{~g} \text { and } \mathrm{Zn} 55 \mathrm{~g} .{ }^{2} \text { Gross energy (Kcal/100g DM), calculated } \\
\text { on the basis of } 5.64,4.11 \text { and } 9.44 \mathrm{Kcal} \mathrm{GE} / \mathrm{g} \text { protein, NFE and lipid, respectively (NRC, 1993). }{ }^{3} \text { Protein to } \\
\text { energy ratio (mg/Kcal). }\end{array}$} \\
\hline
\end{tabular}


Table 3. Growth performance of Nile tilapia (O. niloticus) fed different levels of cooked and un-cooked lupin protein

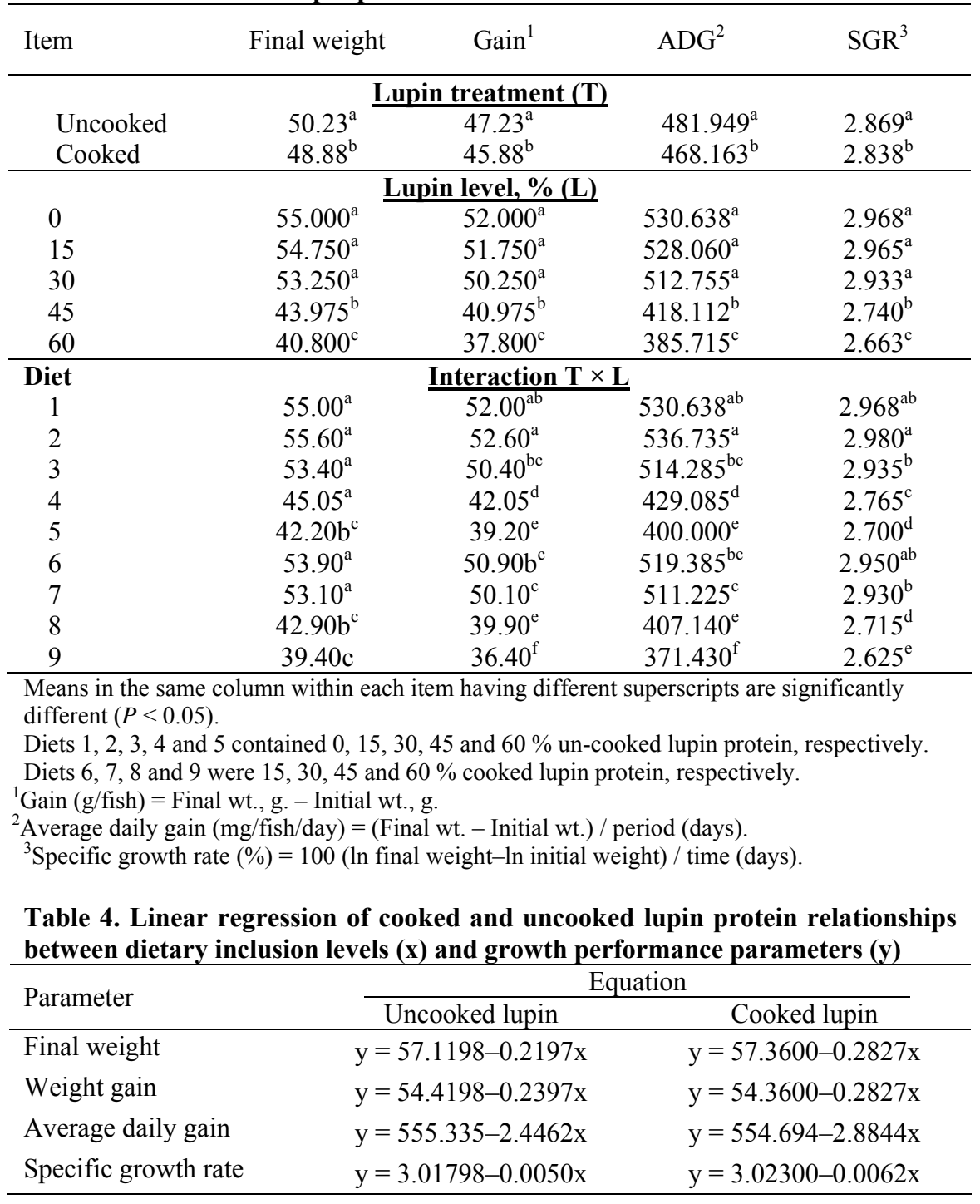

The effect of replacing FM protein by different levels of un-cooked or cooked lupin protein in the diet of Nile tilapia on feed and nutrient utilization is shown in Table 5 and the linear regression molding is presented in Table 6. Fish fed cooked lupin surpassed those fed uncooked lupin in feed intake. On the contrary, fish receiving diets containing un-cooked lupin surpassed those fed cooked lupin in feed conversion ratio $(\mathrm{FCR})$, protein efficiency ratio (PER), protein productive value 
(PPV, \%) and energy utilization (EU, \%). These results are in accordance with the findings of Van Barneveld (1993).

Moreover, as with many other protein sources, cooking or autoclaving of lupin meals reduces the nutritional value of their protein content (De la Higuera et al., 1988; Vandepeer et al., 1999) and increases feed palatability because of alkaloid removal (Robaina et al., 1995). These may support our results of feed intake, PER and PPV. Feed intake, FCR and EU were not significantly $(P>0.05)$ different among fish fed diets containing 0, 15 and $30 \%$ lupin protein instead of FM protein. Burel et al. (1998); Farhangi and Carter (2001) and Glencross, et al. (2004) deemed that the level of inclusion of the yellow lupin did not significantly affect feed intake. It was suggested that the high levels of $L$. albus kernel meal inclusion into fish diets resulted in a weak feed intake due to a loss of palatability caused by high alkaloid contents (Petterson et al., 1997). These excess alkaloids could be removed from Lupin seeds by heat treatment and soaking in water for $24 \mathrm{~h}$ (Robaina et al., 1995). Perhaps this may explain the increased feed intake in fish receiving diets containing cooked lupin compared with those receiving un-cooked lupin. In the same manner, fish receiving the control diet and those fed $15 \%$ lupin protein in their diet had significantly higher $(P<0.05)$ values of PER and PPV than other groups followed by that fed $30 \%$ lupin protein with nonsignificant difference between fish fed the control diet and that fed $30 \%$ lupin protein instead of FM protein in their diet.

Meantime, no significant differences in FCR, PER, PPV and EU were found between fish receiving diets containing 45 and $60 \%$ lupin protein instead of FM protein while, a significant $(P<0.05)$ diet response was seen in feed intake. Similar results were observed by Morales et al. (1994) and Burel et al. (1998).

Because of the variability of feed intake which had considerable impact on the FCR values (De la Higuera et al., 1988), fish fed diets containing 0, 15 and $30 \%$ lupin protein had preferable FCR. Accordingly, Glencross et al. (2004) demonstrated that feed conversion ratio deteriorated significantly at the $50 \%$ lupin level, with a linear regression suggesting a decline in FCR at each inclusion level. Retention efficiency of nitrogen was unaffected by level of inclusion though a significant decline in the efficiency of energy retention was observed with increasing inclusion of yellow lupin. A significant $(P<0.05)$ interaction was found between lupin protein levels $(0,15,30,45$ and $60 \%)$ and lupin treatments (un-cooked and cooked) on feed intake and FCR, while it was nonsignificant $(P>0.05)$ for other parameters.

Carcass proximate analysis results of the experimental fish fed diets containing different levels of un-cooked or cooked lupin protein instead of FM protein are summarized in Table 7 and the linear regression molding is shown in Table 8 . Changes in dry matter of fish carcass in relation to lupin protein levels or lupin treatments were not significant $(P>0.05)$. Furthermore, body ash and gross energy contents in fish were not affected by lupin treatments (un-cooked and cooked). Meanwhile, fish fed un-cooked lupin had significantly higher percentage of protein and ether extract in their body than fish fed cooked lupin. Moreover, fish fed the control diet had significantly $(P<0.05)$ higher carcass protein contents than other fish groups receiving different lupin protein levels in their diets instead of FM protein. Also, the difference in protein contents of fish received 30 and $45 \%$ lupin protein was nonsignificant while, the protein contents of this group differ significantly $(P<$ $0.05)$ from those receiving 45 and $60 \%$ lupin protein. Fish receiving $60 \%$ lupin protein had significantly $(P<0.05)$ lower protein contents. However, there was a 
significant increase in ether extract and gross energy with increasing lupin protein instead of FM protein in the diet. This agrees with the results reported by Morales et al. (1994) In which, fish fed diets containing 45 and $60 \%$ lupin protein exhibited a significantly higher contents of ether extract and gross energy. Nevertheless, the ash content of the groups receiving 0 and $15 \%$ lupin protein instead of FM protein was significantly $(P<0.05)$ higher than that of other groups, while the difference within them was nonsignificant. Conversely, Glencross et al. (2004) stated that the composition of rainbow trout fed the experimental diets was not significantly affected by the inclusion of yellow lupin kernel meal. Hepatosomatic index values were not affected by either lupin levels or lupin treatments. This result is inconsistent with the finding of Glencross et al. (2004) who found an increase in the relative size of gastrointestinal tract with increasing levels of lupin inclusion in the diet of rainbow trout.

Table 5. Feed and nutrient utilization of Nile tilapia (O. niloticus) fed different levels of cooked and uncooked lupin protein

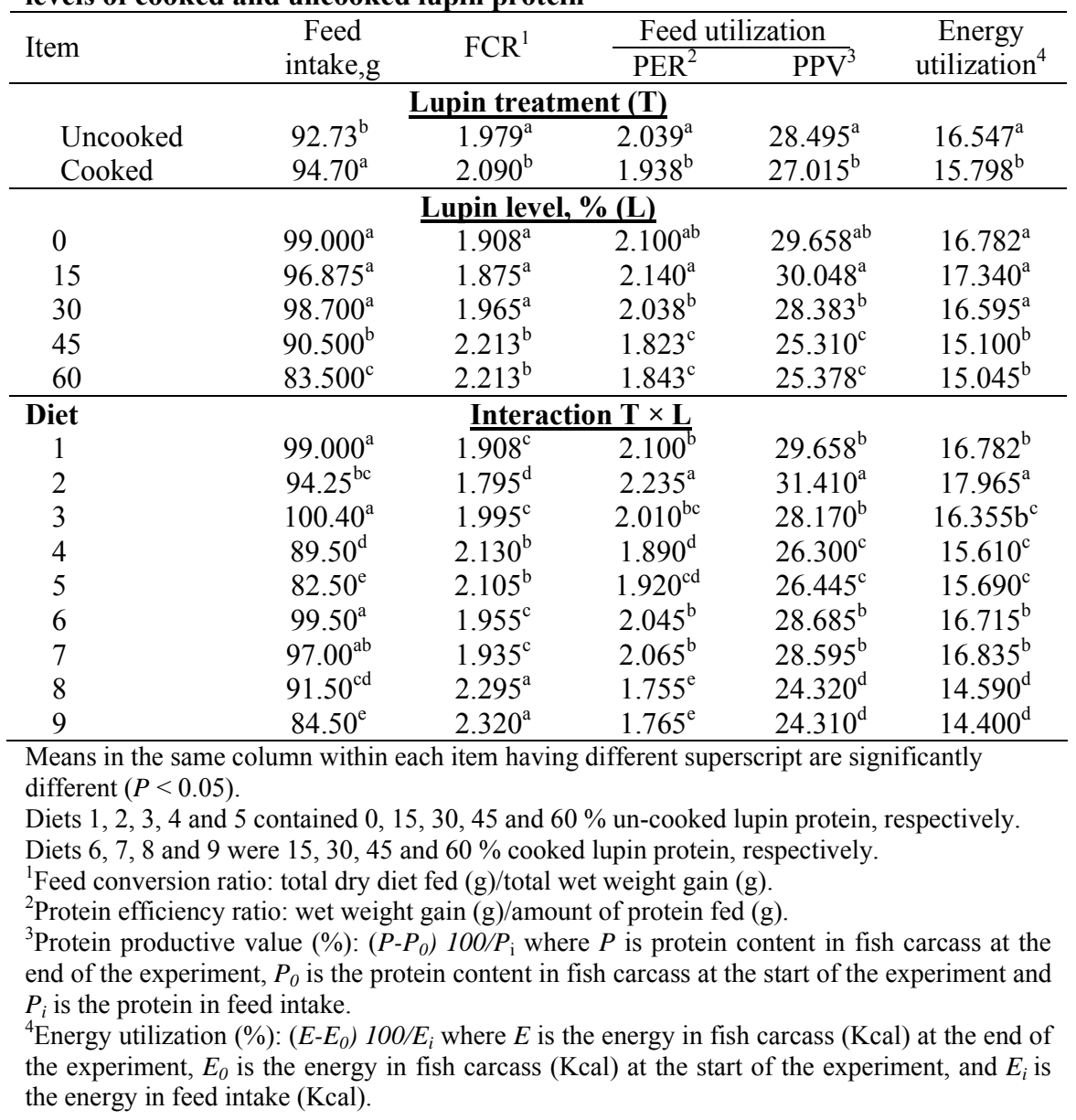


Table 6. Linear regression of cooked and uncooked lupin protein relationships between dietary inclusion levels $(x)$ and feed $\&$ nutrient utilization parameters (y)

\begin{tabular}{llc}
\hline \multirow{2}{*}{ Parameter } & \multicolumn{2}{c}{ Equation } \\
\cline { 2 - 3 } & \multicolumn{1}{c}{ Uncooked lupin } & Cooked lupin \\
\hline Feed intake, $\mathrm{g}$ & $\mathrm{y}=99.4800-0.2250 \mathrm{x}$ & $\mathrm{y}=102.900-0.275292 \mathrm{x}$ \\
Feed conversion ratio & $\mathrm{y}=1.81800+0.0054 \mathrm{x}$ & $\mathrm{y}=1.87200+0.007266 \mathrm{x}$ \\
Protein efficiency ratio & $\mathrm{y}=2.19599-0.0052 \mathrm{x}$ & $\mathrm{y}=2.11400-0.005866 \mathrm{x}$ \\
Protein productive & $\mathrm{y}=30.4988-0.0835 \mathrm{x}$ & $\mathrm{y}=29.8300-0.093833 \mathrm{x}$ \\
value & $\mathrm{y}=17.5880-0.0347 \mathrm{x}$ & $\mathrm{y}=17.0400-0.041433 \mathrm{x}$ \\
Energy utilization & &
\end{tabular}

Table 7. Proximate body composition and hepatosomatic index of Nile tilapia $(O$. niloticus) fed different levels of cooked and un-cooked lupin

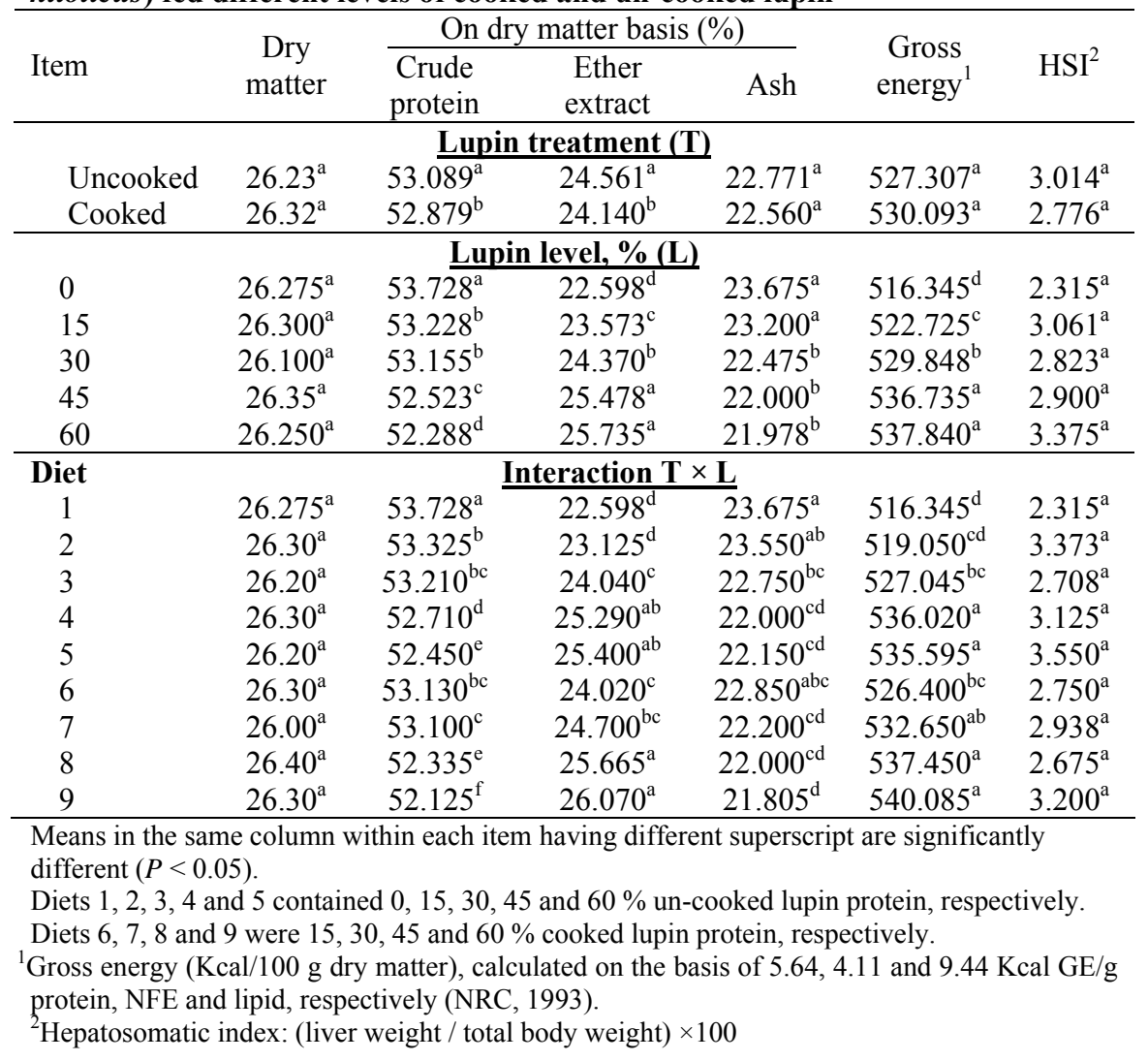


Table 8. Linear regression of cooked and uncooked lupin protein relationships between dietary inclusion levels $(x)$ and carcass composition parameters (y)

\begin{tabular}{lcc}
\hline \multirow{2}{*}{ Parameter } & \multicolumn{2}{c}{ Equation } \\
\cline { 2 - 3 } & Uncooked lupin & Cooked lupin \\
\hline Dry matter & Not Significant & Not Significant \\
Crude protein & $\mathrm{y}=53.7300-0.0214 \mathrm{x}$ & $\mathrm{y}=53.6700-0.0264 \mathrm{x}$ \\
Ether extract & $\mathrm{y}=22.6850+0.0485 \mathrm{x}$ & $\mathrm{y}=22.7440+0.0606 \mathrm{x}$ \\
Ash & $\mathrm{y}=23.5830-0.0271 \mathrm{x}$ & $\mathrm{y}=23.5860-0.0342 \mathrm{x}$ \\
Gross energy & $\mathrm{y}=517.196-0.3369 \mathrm{x}$ & $\mathrm{y}=517.401-0.4231 \mathrm{x}$ \\
Gonado-somatic index & Not Significant & Not Significant \\
\hline
\end{tabular}

Results of the simple economic evaluation of replacing lupin protein for FM protein in the diets of Nile tilapia are presented in Table 9. Mathematically, as lupin protein incremented in fish diets as FM replacer, the feed cost decreased. However, when biological values (e.g. feed conversion ratio) were taken into consideration, diets contained 15, 30 and $60 \%$ un-cooked lupin protein as well as $30 \%$ cooked lupin protein had lowest cost of $\mathrm{kg}$ fish gain and highest change in feed cost per $\mathrm{kg}$ fish gain. Diets contained 15 and $60 \%$ un-cooked in addition to $30 \%$ cooked lupin protein were superior economically as compared to other diets. While on the contrary, diet contained 45 and $60 \%$ cooked lupin protein exhibited lower change in feed cost per $\mathrm{kg}$ fish gain.

Table 9. Cost (L.E.) of feed required for production of one kg gain of Nile tilapia (O. niloticus) fed different levels of un-cooked and cooked lupin whole seed meal protein

\begin{tabular}{ccccc} 
Diets & $\begin{array}{c}\text { Feed cost } \\
\text { (LE/ton feed) }\end{array}$ & $\begin{array}{c}\text { Amount of } \\
\text { feed/kg gain }\end{array}$ & $\begin{array}{c}\text { Cost of kg fish } \\
\text { gain (LE) }\end{array}$ & $\begin{array}{c}\text { Change in feed cost } / \mathrm{kg} \\
\text { gain (\%) compared to } \\
\text { control }\end{array}$ \\
\hline $1^{*}$ & 2611.00 & 1.908 & 4.98 & 0 \\
2 & 2559.96 & 1.795 & 4.60 & -7.63 \\
3 & 2560.38 & 1.955 & 5.01 & +0.60 \\
4 & 2454.40 & 1.995 & 4.90 & -1.61 \\
5 & 2455.35 & 1.935 & 4.75 & -4.62 \\
6 & 2351.45 & 2.130 & 5.01 & +0.60 \\
7 & 2352.88 & 2.295 & 5.40 & +8.43 \\
8 & 2243.40 & 2.105 & 4.72 & -5.22 \\
9 & 2245.46 & 2.320 & 5.21 & +4.62 \\
\hline
\end{tabular}

* Used as a base for calculation

Diets $1,2,3,4$ and 5 contained $0,15,30,45$ and $60 \%$ un-cooked lupin protein, respectively. Diets 6, 7, 8 and 9 were 15, 30, 45 and $60 \%$ cooked lupin protein, respectively.

Cost in LE/ton: Fish meal: 7000, Soybean meal: 2600, Yellow corn: 1150, Un-cooked lupin: 2500, Cooked lupin 2550, Wheat bran: 840, Rice particles: 1000, Vegetable oil: 2700 and Min. \& Vit.: 8000 . 


\section{CONCLUSION}

From the previous results, it may be concluded that un-cooked lupin protein is a useful feed ingredient for Nile tilapia. Furthermore, up to $30 \%$ un-cooked lupin protein can replace FM protein without any reduction in growth, but feed intake problems were encountered with higher replacement of the fishmeal. Economically, 15,30 and $60 \%$ un-cooked in addition to $30 \%$ cooked lupin protein were the best.

\section{REFERENCES}

Allan, G.L., V.P. Gleeson, A.J. Evans and D.A. Stone, 1998. Replacement of fishmeal in diets of silver perch: II. Digestibility of Australian lupins. In: (G.L. Allan and S.J. Rowland, editors), Fishmeal Replacement in Aquaculture Diets for Silver Perch Final Report of Project 93/120-01 to the Fisheries Research and Development Corporation, Canberra, Australia, p 53- 71.

AOAC, Association of Official Analytical Chemists, 1999. Official Methods of Analysis of AOAC, $16^{\text {th }}$ ed. AOAC International, Washington, DC. USA.

Booth, M., G.L. Allan, J. Frances and S. Parkinson, 2001. Replacement of fish meal in diets of silver perch: VI. Effects of dehulling and protein concentration on the digestibility of four Australian grain legumes in diets for silver perch (Bidyanus bidyanus). Aquaculture, 196: 67-85.

Burel, C., T. Boujard, G. Corraze, S.J. Kaushik, G. Boeuf, K.A. Mol, S. Van der Geyten and E.R. Kuhn, 1998. Incorporation of high levels of extruded lupins in diets for rainbow trout (Oncorhynchus mykiss): nutritional value and effect on thyroid status. Aquaculture, 163: 325-345.

Burel, C., T. Boujard, F. Tulli and S. Kaushik, 2000. Digestibility of extruded peas, extruded lupin, and rapeseed meal in rainbow trout (Oncorhynchus mykiss) and turbot (Psetta maxima). Aquaculture, 188: 285-298.

De la Higuera, M., M. Garcia-Gallegro, A. Sanz, G. Cardenete, M.D. Suarez and F.J. Moyano, 1988. Evaluation of lupin seed meal as an alternative protein source in feeding of rainbow trout (Salmo gairdneri). Aquaculture, 71: 37-50.

Farhangi, M. and C.G. Carter, 2001. Growth, physiological and immunological responses of rainbow trout (Oncorhynchus mykiss) to different dietary inclusion levels of dehulled lupin (Lupinus anustifolius). Aquaculture. Res. 32, 329-340.

Glencross, B. D., Curnow, J. G., Hawkins, W. and Felsing, M. 2002. Preliminary evaluation of yellow lupins (Lupinus luteus) kernel meal as an alternative protein source in the diet of sea-cage reared rainbow trout, Oncorhynchus mykiss. J. World Aquaculture. Soc. 33, 287- 296.

Glencross, B.D., J.G. Curnow, W. Hawkins, G. Kissil and D.S. Petterson, 2003. Evaluation of the feed value of a transgenic strain of the narrow-leaf lupins (Lupinus angustifolius) in the diet of the marine fish Pagrus auratus. Aquaculture. Nutr. 9: 197-206.

Glencross, B.D., E. David, W. Hawkins and J. Brian, 2004. Evaluation of dietary inclusion of yellow lupin (Lupinus luteus) kernel meal on the growth, feed utilization and tissue histology of rainbow trout (Oncorhynchus mykiss). Aquaculture, 235: $411-422$.

Glencross, B.D., E. David, R. Neil, W. Hawkins, M. Peter, D. Ken, J. Brian, H. David, M. Linco, S. Mark and S. Sofie, 2006a. The influence of the dietary 
inclusion of the alkaloid gramine, on rainbow trout (Oncorhynchus mykiss) growth, feed utilization and gastrointestinal histology. Aquaculture, 253: 512522.

Glencross, B.D., W. Hawkins, E. David, R. Neil, D. Ken, M. Ross, M. Peter and S. Sofia, 2006b. Evaluation of the nutritional value of prototype lupin protein concentrates when fed to rainbow trout (Oncorhynchus mykiss). Aquaculture, 251: 66-77.

Gomes, E.F., P. Rema and S.J. Kaushik, 1995. Replacement of fish meal by plant proteins in the diet of Rainbow Trout (Oncorhynchus mykiss): digestibility and growth performance. Aquaculture, 130: 177-186.

Hardy, R.W., 1996. Alternate protein sources for salmon and trout diets. Anim. Feed Sci. Technol. 59, 71-80.

Harris, D.J. and J. Jago, 1984. Report on chemical composition of sweet lupin seed from Western Australia. Government Chemical Laboratories. Perth. Australia.

Hepher, B., 1988. Nutrition of pond fishes. ISBN $1^{\text {st }}$ ed., The Press Syndicate of the University of Cambridge, UK.

Hughes, S.G., 1988. Assessment of lupin flour as a diet ingredient for rainbow trout (Salmo gairdneri). Aquaculture, 71: $379-385$.

Jauncey, K. and B. Ross, 1982. A guide to tilapia feeds and feeding. ISBN $1^{\text {st }}$ ed., Institute of Aquaculture Univ. of Stirling. Scotland, U. K.

Jayaram, M.G. and H.P. Shetty, 1981. Formulation, processing and water stability of two pelleted fish feeds. Aquaculture, 23: $355-359$.

Kissil, G.W. and I. Lupatsch, 2000. Growth performance and nutrient utilization of Gilthead seabream (Sparus auratus) fed a transgenic lupin (Lupinus angustifolius L.) with enhanced methionine content. In: The $9^{\text {th }}$ International Symposium on Nutrition and Feeding in Fish. 21-25 May 2000, Miyazaki, Japan.

Morales, A.E., G. Cardenete, M. De la Higuera and A. Sanz, 1994. Effects of dietary protein source on growth, feed conversion and energy utilization in rainbow trout, Oncorhynchus mykiss. Aquaculture, 124: 117-126.

NRC, 1993. Nutrient Requirements of Warmwater Fishes and Shellfishes, National Research Council, rev. ed., National Academy Press, Washington, DC, USA.

Palmegiano, G.B., F. Daprà, G. Forneris, F. Gai, L. Gasco, K. Guo, P.G. Peiretti, B. Sicuro and I. Zoccarato, 2006. Rice protein concentrate meal as a potential ingredient in practical diets for rainbow trout (Oncorhynchus mykiss). Aquaculture, 258: 257 - 367.

Petterson, D.S., 2000. The use of Lupins in Feeding Systems-Review. Asian Australian Journal of Animal Science, 13 (6): 861-882.

Petterson, D.S., G.I. Jenkins and J. Hutabarat, 1998. The use of lupins in aquaculture. Proc. $3^{\text {rd }}$ AEP Conf. Valladolid, Spain, pp. 456-7.

Petterson, D.S., S. Sipsa and J.B. Mackintosh, 1997. The Chemical Composition and Nutritive Value of Australian Pulses. Grains Research and Development Corporation, Canberra, Australia. pp 65.

Refstie, S., B. Glencross, T. Landsverk, M. Sørensen, L. Einar, H. Wayne and K. Åshild, 2006. Digestive function and intestinal integrity in Atlantic salmon (Salmo salar) fed kernel meals and protein concentrates made from yellow or narrow-leafed lupin. Aquaculture. doi:10.1016/j.aquaculture.2006.07.046.

Robaina, L., M.S. Izquierdo, F.J. Moyano, J. Socorro, J.M. Vergara, D. Montero and H. Fernandez-Palacios, 1995. Soybean and lupin seed meals as protein sources in 
diets for gilthead seabream (Sparus aurata): nutitional and histological implications. Aquaculture, 130: 219-233.

Saraç, H.Z., H.B. Thaggard, J. Rose, B. Kelly and M.R. Gravel, 1998. Utilization of Plant Protein Sources. In: (D.M. Smith, ed.), Fishmeal Replacement in Aquaculture Diets for Prawns. Final Report of Project 93/120-02 to the Fisheries Research and Development Corporation,Canberra, Australia.

Sitja'-Bobadillaa, T., S. Peña-Llopisa, P. Go'mez-Requenia, F. Me'daleb, Kaushikb, S. and J. Pe'rez-Sa'ncheza, 2005. Effect of fish meal replacement by plant protein sources on non-specific defence mechanisms and oxidative stress in gilthead sea bream (Sparus aurata). Aquaculture, 249: 387-400.

Smith D.M., G.L. Allan, K.C. Williams and C.G. Barlow, 2000. Fishmeal replacement research for shrimp feed in Australia. In: Proceedings of $5^{\text {th }}$ International Symposium on Aquatic Nutrition. 19-22 November 2000, Merida Yutacan, Mexico.

Steel, R.G. and J.H. Torrie, 1980. Principles and procedures of statistics: A Biometrical Approach. McGraw-Hill, New York, USA.

Tacon, A.G. and A. Jackson, 1985. Utilization of conventional and unconventional protein sources in practical feeds, p. 119-145. In C.B. Cowey, A.M. Mackie and J.G. Bell (eds.) Nutrition and Feeding in Fish. Acedemic Press, London.UK.

Van Barneveld, R.J., 1993. Effect of heating proteins on the digestibility, availability and utilization of lysine by growing pigs. Ph. D. Thesis, University of Queensland, Brisbane, Australia.

Vandepeer, M.E., R.J. van Barneveld, P.W.Hone and J.N. Havenhand, 1999. The digestibility of raw, autoclaved and phytase treated legumes in greenlip abalone, Haliotis laevigata. Proceedings of the 6th Annual Abalone Aquaculture Workshop, April 1999, World Aquaculture Society Conference, Sydney, New South Wales. Fisheries Research and Development Corporation, Canberra.

Viola, S., Y. Arieli and G. Zohar, 1988. Unusual feedstuffs (tapioca and lupin) as ingredients for carp and tilapia feeds in intensive culture. Israeli Journal of Aquaculture- Bamidgeh, 40: 29-34.

Williams, K.C., 1998. Efficacy of utilization of different feed sources as measured by summit dilution. In: (K.C. Williams, ed), Fishmeal Replacement in Aquaculture Feeds for Barramundi. Final Report of Project 93/120-03 to the Fisheries Research and Development Corporation, Canberra, Australia. 
تأثير التظذية على بروتين مسحوق بذور الترمس على نمو البلطى النيلى المربى فى تنكات

طارق محمد أحمد سرور

قسم الإنتاج الحيوانس والسمكى. كلية النزراعة، سابا باشا، جامعة الإسكندرية

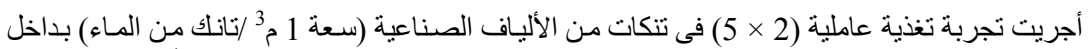

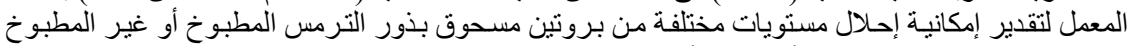

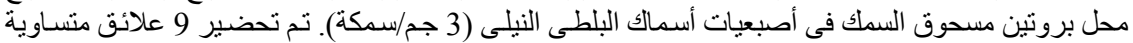

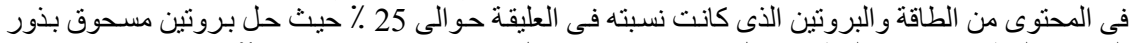

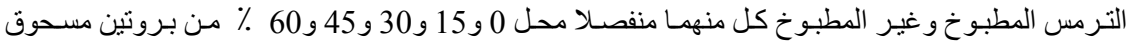

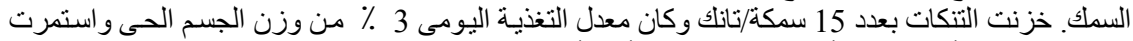

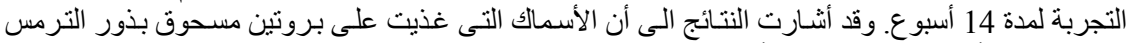

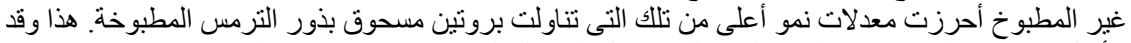

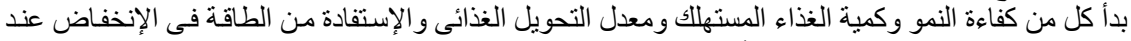

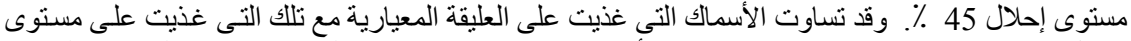

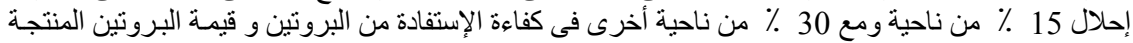

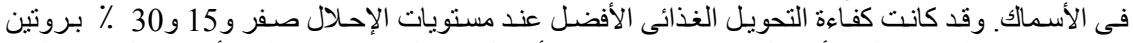

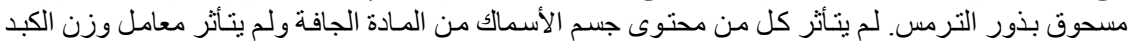

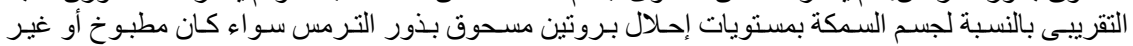

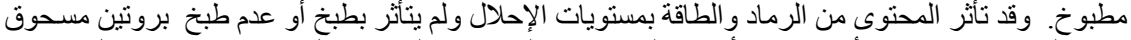

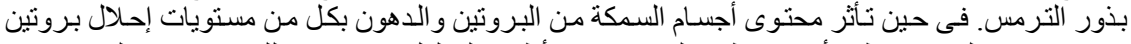

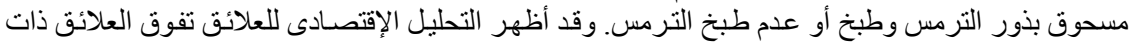

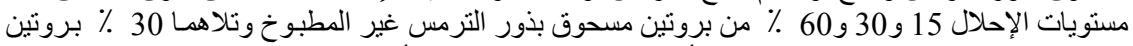

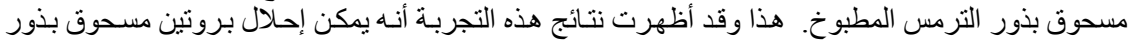
الترمس غير المطبوخ بنسبة تصل الى 30٪ من بروتين مسحوق السمك فى علائق البلطى النيلى بذون إعاقة 